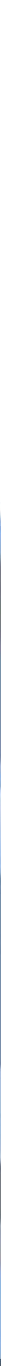

$9^{\circ}$ CONGRESO 2. CENTROAMERICANO DE H IS TO R I A
Universidad de Costa Rica

ISSN 1409- 469X

Fecha de recepción: 15 de mayo 2008 Fecha de aceptación: 30 de mayo 2008

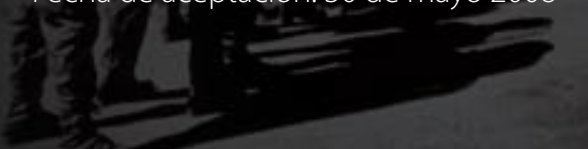

“Los primeros automóviles en Costa Rica: el impacto en las importaciones, la legislación y la publicidad. 1907 - 1930."

Miembros del Consejo Editorial:

Dr. Ronny Viales, Dr. Juan José Marín

Editores Técnicos:

Allan Fonseca, Andrés Cruz, Gabriela Soto

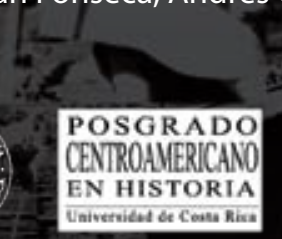


Indexaciones: Repositorio de Revistas UCR, DIALNET, Latindex, REDALYC Directorio y recolector de recursos digitales del Ministerio de Cultura de España, Directory of Open Access Journals. Diálogos Revista Electrónica de Historia ISSN 1409- 469X. Número especial 2008. Dirección web: http://historia.fcs.ucr.ac.cr/dialogos.htm

\title{
"Los primeros automóviles en Costa Rica: el impacto en las importaciones, la legislación y la publicidad. 1907 - 1930.”
}

\author{
Alejandro J. Quesada Varela \\ Bachiller en Historia. Universidad de Costa Rica. \\ Heredia, Costa Rica. Residencial El Río \# 104 \\ 2260-11-37 // 8829-01-74 \\ Jalejandro_20@yahoo.com.mx
}




\section{Introducción.}

La investigación que pretendemos realizar buscara determinar ¿cual fue el impacto que tuvo la aparición del automóvil sobre las importaciones, la legislación y la publicidad (en la prensa escrita) del Valle Central de Costa Rica? Al tratar de determinar el impacto que tuvo el automóvil sobre el Valle Central, estaremos evaluando los cambios paulatinos, principalmente en las importaciones, en la legislación y en la información que brindaba la publicidad de los periódicos de la época respecto al automóvil.

La investigación histórica que se busca realizar, es una investigación bastante novedosa en cuanto a los objetivos que se ha planteado. Esto debido a que la mayoría de estudios realizados que han tratado el tema de los automóviles en Costa Rica, han tenido otra perspectiva, un poco alejada de la histórica. La perspectiva con la que ha sido tratado el tema ha sido más que todo desde una visión técnica, inmersa dentro de estudios realizados por ingenieros civiles, arquitectos $\mathrm{u}$ otra serie de profesionales afines a estos campos, los cuales han analizado el tema dejando de lado cualquier aspecto histórico y se han concentrado principalmente en estudios acerca de la problemática del congestionamiento vial que ha sufrido la ciudad capital en las últimas décadas y en proyectos que pueden darle una solución ha dicho problema. Aparte de esto es importante mencionar que dichos estudios presentan una delimitación temporal mucho más reciente (década de 1980 y 1990) en comparación con nuestra investigación.

La delimitación espacial de la investigación se centrara en Costa Rica, específicamente en el Valle Central. La principal razón que existe para situar espacialmente el trabajo en este lugar, radica en el hecho de que posiblemente haya sido en el Valle Central (las principales ciudades en conjunto) donde el automóvil haya tenido su mayor acogida y se haya convertido en un elemento cotidiano (conforme fue aumentando la cantidad de los mismos).

Temporalmente la investigación tiene una delimitación que abarca entre los años de 1907 hasta 1930. Se ha escogido este período de tiempo debido a que tanto el año de 1907 como el de 1930 vienen a ser años importantes y representativos dentro de la historia automovilística de nuestro país.

Nuestra investigación girara en torno a varios objetivos. Un objetivo general el cual buscara determinar el impacto que tuvo la aparición del automóvil en las importaciones, la legislación y la publicidad (de la prensa escrita) en el Valle Central de Costa Rica el período 1907-1930. Este objetivo a su vez se dividirá en tres objetivos específicos que buscan: Determinar la dinámica 
de importación de automóviles y artículos afines a los mismos durante el período en estudio; analizar de manera comparativo el Reglamento para el servicio de automóviles en la ciudad de San José dictado en 1910 y la primera Ley de Tránsito dictada en 1926, a fin de determinar las posibles innovaciones que se presentan en la segunda y finalmente; analizar y comparar la publicidad relacionada con los automóviles que aparecen en la prensa escrita de la época, a fin de identificar los posibles cambios que se presentan en los mismos.

Estos tres objetivos darán paso al desarrollo de tres capítulos. El capítulo I titulado Los automóviles y las importaciones costarricenses contiene información acerca de lo que fue la dinámica de importación de los automóviles y autocamiones, así como de esta dinámica en el caso de bienes afines como la gasolina, el asfalto y las llantas de caucho. También se hace un análisis los principales socios comerciales costarricenses en términos de importación de automóviles y afines.

El capítulo II presenta un análisis de lo que fue el primer intento por regular el transitar de vehículos automotores en Costa Rica el cual se promulgo en el año 1910, paralelamente se analiza la primera Ley de Tránsito en la historia de nuestro país, la cual data de 1926 y finalmente este capítulo concluye haciendo un análisis comparativo de ambas legislaciones donde se determinará cuales fueron los principales cambios que presento la legislación de 1926 con relación a la de 1910 .

Finalmente el capítulo III se centrará en analizar la publicidad presente en una muestra de periódicos de la época, a fin de determinar cual era la información que brindaba la publicidad de la época con relación a los automóviles mismos y a sus productos afines.

\section{Capítulo I}

\section{Los automóviles y las importaciones costarricenses.}

\section{Introducción}

En el presente capítulo se buscará realizar un análisis lo más detallado posible respecto a lo que fue la importación de automóviles y afines durante las primeras tres décadas del siglo XX en Costa Rica. Dicho análisis se dividirá en tres secciones, cada sección corresponderá al estudio de una temática en específico.

La sección inicial se centrara directamente en el estudio de la importación de automóviles y autocamiones durante las tres primeras décadas del siglo XX, allí se profundizará en lo que fue 
la aparición del automóvil como un elemento dentro de las importaciones nacionales.

La segunda sección tiene cómo objetivo el determinar como se fue desarrollando la importación de elementos afines a los automóviles. Esta sección estudiará el caso de tres productos muy ligados a los automóviles, los cuales son: el asfalto, la gasolina y a partir de la década de 1920, la importación de llantas de caucho..

La tercera y última sección analizará la procedencia de las importaciones de automóviles y de elementos afines a los mismos. En esta sección se buscara dejar claro cuales fueron los principales países de donde se importaban los automóviles, y los cambios que se pudieron haber producido durante las décadas de estudio.

\section{Importación de automóviles y autocamiones en las primeras tres décadas del siglo XX.}

La economía costarricense hasta nuestro período de estudio, se había caracterizado por ser una economía agro exportadora, su introducción a la dinámica comercial mundial se dio gracias al éxito que tuvo la siembra y posterior exportación de café a países con economías sumamente fuertes, entre las que destacaban Gran Bretaña, Francia y Alemania entre los países europeos y economías que iban en continuo crecimiento como lo era el caso de Estados Unidos (a partir de este momento EE.UU.). Otro producto que vino a tener una influencia bastante considerable dentro de la economía costarricense lo constituyo el banano. Este producto a su vez tuvo como su principal mercado y destino, el mercado estadounidense. Es gracias a estos productos, principalmente, que Costa Rica se introduce dentro del mercado mundial y llega a establecer una serie de relaciones comerciales y económicas con países con fuertes economías. Es a partir de este momento que nuestro país comienza a considerar a estas naciones como socios comerciales, con los cuales desarrollará una dinámica comercial en la cual los países se verán beneficiados con los productos que se exportan desde Costa Rica, y nuestro país se beneficiará en la medida en la que pueda importar mercancías provenientes de dichas naciones. Es dentro de esta dinámica comercial donde se inicia la importación de automóviles, autocamiones y afines a nuestro país.

La importación de automóviles a Costa Rica tuvo su inicio durante la primera década del siglo XX. Fue durante estos primeros años del nuevo siglo que los automóviles y elementos afines a los mismos empiezan a formar parte de las importaciones y de las estadísticas comerciales de nuestro país. La primera referencia respecto a la importación de automóviles de que disponemos data de 1907. Dichas estadísticas no contemplan la cantidad de automóviles importados, lo que 
nos presenta es su equivalente en kilogramos, esto debido a que era una práctica dentro de las aduanas estimar las mercancías provenientes del extranjero en kilogramos, por lo tanto, no podemos determinar un número exacto de automóviles importados, lo que si podemos estimar es el peso aproximado de un vehículo producido en esos años. El peso estimado para un vehiculo sería de $500 \mathrm{Kg}$., tomando como base el peso del modelo Ford T fabricado entre 1909 y 1924.

Este dato nos ayudara, a partir de ahora, a tener una leve estimación de la cantidad de automóviles importados durante las primeras tres décadas del siglo pasado. Planteamos que será una leve estimación debido a que este valor puede cambiar dependiendo de la marca y año del vehículo. De igual forma este dato será solo una estimación y no un dato real ni una cifra con la cual trabajaremos a lo largo de esta sección, a la hora de analizar las importaciones de automóviles y autocamiones. Esto debido a que la categoría presente en los Anuarios Estadísticos de Costa Rica (nuestra principal fuente para este capítulo) no realiza una división clara entre kilogramos pertenecientes a automóviles-autocamiones y kilogramos pertenecientes a accesorios, sino que suma ambos valores para dar un valor total de kilogramos importados. Ahora bien otra aclaración que consideramos prudente realizar antes de entrar de lleno en el análisis, es que si bien las cifras en kilogramos presentan un equivalente en colones, no contamos con la información que nos pueda indicar el valor real de mercado en colones de un automóvil, por lo que tampoco podemos utilizar este dato para calcular la cantidad exacta de automóviles importados durante un año. De ahí que nuestro análisis utilizará los datos de importación en términos de peso (kilogramos) y en términos de valor de mercado (valor en colones) como lo presentan los Anuarios Estadísticos.

\section{Importación de automóviles.}

La primera parte de este análisis, centrara su atención en lo que fue la importación de automóviles desde 1907 hasta 1930. La importación de automóviles hacia Costa Rica durante las primeras tres décadas del siglo XX paso por tres procesos importantes. Un primer período el cual abarca desde 1907 hasta 1910, este primera etapa se puede considerar como el período en el cual lo automóviles hacen su ingreso dentro de la dinámica comercial costarricense. Esta etapa puede ser definida como la etapa de introducción.

El segundo período de la dinámica de importación de automóviles en Costa Rica esta caracterizado por ser la etapa en cual se da un incremento y desarrollo de las importaciones. Esta 
etapa inicia en el año de 1911 y finaliza en el año de 1920, y puede ser definida como la etapa de desarrollo.

El ultimo período y tal vez el más importante dentro de este análisis de las importaciones de automóviles inicia en 1921 y se extiende hasta 1930, El mismo se caracteriza por ser el período en el cual las importaciones de automóviles sufren un fuerte incremento y se consolidan dentro de la dinámica comercial costarricense. Esta etapa puede definirse como la etapa o período de consolidación de las exportaciones.

Pues bien la mejor manera de ver estos procesos de evolución que sufrieron las importaciones de automóviles es mediante los datos.

Los datos presentes en el Cuadro 1 vienen a ratificar el planteamiento expuesto anteriormente, en donde las importaciones de automóviles en el período en estudio, atraviesan tres procesos. Del año 1907 al año 1910, las importaciones de automóviles están hasta ahora introduciéndose dentro de la dinámica comercial costarricense, al punto que vemos que para este primer período el total de kilogramos importados fue de $25472.2 \mathrm{~kg}$ y su equivalente en colones de $\$$ 62242.65. La información presente en el Cuadro 1 a su vez muestra que durante la primera década del siglo XX hubo una tendencia de crecimiento en las importaciones de automóviles, dicho aumento si bien no podemos percibirlo por cantidad de automóviles importados, si podemos percibirlo en términos de peso, debido a que año a año, la cantidad de kilogramos importados relacionados con los automóviles creció y consecuentemente a ello el valor en colones de dichas importaciones también fue en aumento. Este proceso de crecimiento solo sufrió una fluctuación (descenso) para el año de 1910. El descenso que se presentó en 1910 más que querer marcar una tendencia, puede considerarse como un hecho aislado, que se dio debido a la falta de importación de automóviles provenientes del Reino Unido y de Alemania.

El segundo período, el cual va de 1911 a 1920, y al cual denominamos el proceso de desarrollo de las importaciones de automóviles, arroja cifras totales equivalentes a 598054.5kg importados y un equivalente en colones de $\$ 1160371.62$ Vemos que entre el primer período y este segundo hay una diferencia bastante marcada en cuanto a las cifras totales tanto en kilogramos como en colones. Lo expuesto anteriormente viene a reflejar un poco el desarrollo que se estaba dando en el segundo decenio del siglo XX. Un desarrollo que estaba sentando las bases para la posterior consolidación de la dinámica de importación de automóviles (en el período siguiente) y de todos aquellos bienes que giran en torno a ellos. Es durante este período de estudio que el automóvil 
se comienza a desarrollar como una mercancía con cierto peso dentro de la economía nacional costarricense, peso que con el paso de los años seguirá creciendo, pero que para ese momento todavía no había logrado consolidarse como un producto de importancia comercial.

El último período, el cual hemos denominado el período de consolidación de las importaciones de automóviles, presenta cifras totales equivalentes a $3491515 \mathrm{~kg}$ y su equivalente en colones a $\$ 9$ 311760; como vemos cifras muy superiores tanto en peso como en valor económico a las presentadas por los dos períodos anteriores. Esto a su vez viene a corroborar nuestra hipótesis, de que es en el período que inicia en 1921 y finaliza en 1930 en donde se la consolidación definitiva de los automóviles como productos importantes dentro de la dinámica comercial costarricense.

Si transformamos la información disponible en el Cuadro 1 en un gráfico lineal (Gráfico 1) podemos apreciar que la curva en este gráfico va a presentar características ascendentes casi en todo su recorrido tanto para el valor en kilogramos como en colones y será solamente en el período que corresponde a la I Guerra Mundial (y debido a que los principales socios comerciales costarricenses -EE.UU., Alemania y Reino Unido- se encuentran en plena guerra) y a los años de 1921 y 1922 (crisis cafetalera costarricense) ${ }^{1}$ y 1929, 1930 (crisis y depresión económica que atravesaron los mercados mundiales) que la curva tienda a descender.

\section{Importación de autocamiones.}

Lo primero que debemos mencionar, es que el proceso de importación de autocamiones en Costa Rica se inicia a partir de 1920, momento en el cual se esta comenzando a consolidar el automóvil como parte de la sociedad costarricense y el mismo esta comenzando a adquirir importancia dentro de la dinámica comercial de nuestro país.

Algo importante que vale la pena mencionar es que los autocamiones son automóviles en si, pero con una serie de características particulares. Este automóvil fue concebido para que desarrollara una serie de actividades en concreto. El autocamión viene siendo una especie de automóvil especializado, de ahí que sea considerado como un elemento aparte y separado del automóvil en las listas de productos importados por nuestro país y que a su vez cuente con accesorios determinados, diferentes a los accesorios de los automóviles ordinarios.

1 Ana María Botey, “Costa Rica entre guerras: 1914-1940”. Cuadernos de Historia de las Instituciones de Costa Rica, N 6 (Editorial de la Universidad de Costa Rica, 2005) Pág. 58 
De esta división que realizan las estadísticas respecto a automóviles y a autocamiones, y al hecho que estos últimos llegan a introducirse dentro de la dinámica comercial y de importación de vehículos automotores en la llamada etapa de consolidación de la importación en el mercado costarricense, podríamos suponer, y esto claro esta es a manera de hipótesis, que la introducción de este tipo de vehículo se da para solventar necesidades especificas, necesidades que el automóvil no podía solventar. Partiendo del hecho que los automóviles que llegaron a Costa Rica durante las tres primeras décadas del siglo XX eran más un bien de lujo, el cual estaba destinado a la diversión y al transporte privado, es que podemos considerar que la aparición de los autocamiones se debe a la búsqueda de parte de la sociedad costarricense por solventar problemas ligados al transporte de mercancías y pasajeros. Es en este sentido donde podemos establecer un vínculo entre los autocamiones y el trasporte visto como un elemento dentro de los procesos de producción. En términos simples, los autocamiones vienen a ser mayoritariamente vehículos destinados al trabajo y no a la diversión ni al trasporte privado de sus dueños.

El Cuadro 2 y el Gráfico 2 nos muestran la evolución y tendencia de las importaciones de autocamiones durante la tercera década del siglo XX. Como vemos en ambos casos, se nota que las importaciones de autocamiones desde su aparición en 1920, se mantuvo en términos generales en ascenso, y al igual que en el caso de los automóviles, los momentos en los cuales las cifras y la curva (en le Grafico 2) presentan un descenso se da en los años de 1922 y 1923, producto de una crisis que sufrió el sector exportador cafetalero costarricense, principal financiador de estas importaciones, y en 1930, momento en el cual el mundo esta atravesando una depresión económica, depresión que afectaría tanto las exportaciones como las importaciones costarricenses y mundiales.

La tendencia al crecimiento en términos generales, que mostraron las importaciones de autocamiones desde su aparición y a lo largo de toda la década de 1920 muestra la importancia que estaba adquiriendo la importación de los mismos en términos generales dentro del mismo mercado de importación de vehículos automotores. El Gráfico 3 y 4 son una muestra de la importancia de fueron adquiriendo los autocamiones en la dinámica de importación de vehículo automotores.

Como podemos observar tanto en el Gráfico 3 como en el 4, la curva de autocamiones presenta una gran similitud en cuando a su desarrollo respecto a la curva de automóviles, lo que hace suponer que su dinámica de importación siguió los mismos parámetros a partir de 1920, 
momento en el cual se comienza a registrar la importación de autocamiones en Costa Rica. De igual forma vemos como para el lustro que inicia en 1920 y que finaliza en 1925, se dio un descenso en la curva de las importaciones de automóviles, descenso que puede estar justificado en parte por la introducción al mercado costarricense de los autocamiones y por la crisis de las exportaciones cafetaleras que atravesó el país en este período, crisis que ha su vez afectaría la dinámica de importación.

A continuación expresaremos en términos porcentuales el valor de las importaciones de autocamiones y de automóviles respecto a los valores totales de importación de vehículos automotores.

En cuanto a los valores de importación expresados en colones, los autocamiones representan el 31.2\% del total de las importaciones de vehículos automotores para el período de 1920 a 1930. El otro 68.8\% representa el valor de las importaciones de automóviles. En términos de peso, los autocamiones representan el 35.4 \% del total de importaciones de vehículos, mientras que el restante $64.6 \%$ corresponde a la importación de automóviles.

En síntesis, vemos que tanto la importación de automóviles como la importación de autocamiones a lo largo de nuestro período de estudio, estuvo marcada desde su inicio por un constante ascenso, ascenso que a su vez viene a corroborar la hipótesis de los tres procesos por los cuales pasó la importación de vehículos en las tres primeras décadas del siglo XX en Costa Rica. De igual forma un análisis de pesos y valor comercial sugiere que los automóviles eran más caros que los autocamiones.

\section{Importación de gasolina, asfalto y llantas de caucho.}

Desde la introducción del automóvil a la sociedad costarricense en 1907, la dinámica de importación de productos fue cada vez acoplándose más e introduciendo bienes afines en torno a estos. Bienes o productos como la gasolina, el asfalto y las llantas de caucho hacen su aparición en las estadísticas económicas costarricenses ligadas a la importación. Cada uno de estos bienes presentará una relación particular con los automóviles. A través de este análisis, trataremos en la medida de lo posible, de conocer la dinámica particular e individual que desarrollaron estos productos en las tres primeras décadas del siglo XX, y a su vez establecer la relación que mantuvieron los mismos con la importación de automóviles. 


\section{Gasolina.}

Es claro, según las estadísticas y lo que conocemos, que la gasolina era un producto que se utilizaba en Costa Rica desde antes que el primer automóvil circulara por los caminos costarricenses. Esto se debía a que una serie de actividades productivas utilizaban motores de combustión interna para desarrollar sus labores. A ciencia cierta no sabemos cuales eran dichas actividades, lo que si tenemos claro es que antes de que se comenzara a importar automóviles, la gasolina ya formaba parte de los productos que se traían del exterior. En la medida de lo posible, las estadísticas de importación puede corroborar esto, debido que para 1907, cuando se importa el primer automóvil, Costa Rica importaba 55652 Kg., correspondientes a gasolina (la gasolina era importada y transportada en recipientes metálicos, de ahí la posibilidad de establecer el peso en kilogramos) los cuales tenían un equivalente en colones de $\$$ 6944. Dicha cantidad de gasolina es muy poco probable que fuera empleada para alimentar la casi inexistente flota vehicular. Por tal motivo es que se puede pensar que si bien la importación de gasolina aumentó en gran medida debido a la importación de automóviles, esta no surgió en el mismo momento en que surgió el automóvil como un nuevo producto de importación.

Más que pensar que la cantidad de gasolina fue en aumentó año a año debido a la importación de nuevos automóviles, se debe afirmar, y esto lo podemos hacer gracias a la información que nos brindan los anuarios estadísticos. Como lo representa el Gráfico 5, la importación de gasolina se mantuvo en constante aumento a partir de 1907.

Como lo mencionamos anteriormente, la importación de gasolina no se debe a la llegada de los automóviles, pero si fue gracias a este nuevo medio de trasporte que sufrió un importante despegue. Si comparáramos el Gráfico 1 con el Gráfico 5, veríamos que existe cierto paralelismo entre el desarrollo y consolidación de las importaciones de automóviles y el creciente aumento en las importaciones del hidrocarburo.

\section{Asfalto.}

El asfalto al igual que la gasolina es un producto que presenta cierta relación con los automóviles, aunque su relación no sea estrictamente de dependencia. La relación entre estos dos productos puede considerarse como una relación de beneficio unilateral. Planteamos que es unilateral porque con la importación de asfalto solamente los automóviles se benefician, 
aunque más que los automóviles mismos, serán los dueños y conductores de estas máquinas los verdaderos beneficiados. El mayor beneficio para estas personas con la importación de asfalto, se presenta en las calles y caminos que conforman la red vial de nuestro país, la cual a inicios del siglo XX más que ser un entramado de carreteras, estaba constituida por un conjunto de caminos de tierra y lastre en la mayoría de los casos y caminos macadamizados ${ }^{2}$ en las vías más importantes de las ciudades principales.

La importación de asfalto a lo largo de nuestro período de estudio puede dividirse en dos etapas, una primera etapa que inicia en 1907 y se extiende hasta el año de 1926, exceptuando 1917, en la cual la importación de asfalto presenta valores muy bajos tanto en términos de peso (kilogramos) como en valor económico (colones). El desarrollo de esta primera etapa de la importación de asfalto la podemos ver en el Gráfico 6.

La segunda etapa de importación de asfalto que inicia en 1927 (las importaciones de asfalto de 1917 se deben incluir aquí), se caracteriza por presentar valores mucho más altos que la etapa anterior. Los años que se consideran parte de esta etapa presentan valores superiores a los 80 000kg. y a los $\$ 400000$ importados. Es aquí mismo donde se da el despegue de las importaciones de este producto, debido en parte a la puesta en marcha de proyectos para construcción de calles y caminos asfaltados, por parte de los gobiernos costarricenses. El gráfico 6 también nos muestra la dinámica de importación de asfalto para la etapa que inicia en 1927.

Como hemos podido ver en esta sección del capítulo, la importación de asfalto no presentó una evolución similar a la presentada por la importación de automóviles, autocamiones y gasolina para el período en estudio, esto se debió al carácter de bien secundario y no indispensable que presentaba el asfalto dentro de los productos afines a los automóviles. El asfalto puede entenderse como un bien secundario en la medida en que no es indispensable para que los automóviles transiten por los caminos, sino que forma parte de los procesos de modernización de la red vial costarricense.

$2 \quad$ Patricia Fumero Vargas. “Cultura y sociedad en Costa Rica 1914-1950”. Cuadernos de Historia de las Instituciones de Costa Rica. № 16. (Editorial de la Universidad de Costa Rica, 2005) Pág. 1 


\section{Las llantas de caucho}

Si bien los primeros automóviles que circularon por nuestras carreteras, probablemente lo hicieron sin utilizar llantas (las ruedas tenían una fabricación similar a la de los carruajes y coches, en donde la superficie de rodamiento estaba fabricada de madera), ya para la segunda década del siglo XX si hacían uso de este dispositivo. Desconocemos los motivos por los cuales la importación de llantas de caucho no se contabilizó dentro de los anuarios estadísticos sino hasta el año de 1920. Por lo tanto nuestro análisis de dicho producto iniciará a partir de esa fecha. De igual forma desconocemos por qué el anuario estadístico de Costa Rica del año 1923, no contempla la información correspondiente a la importación de llantas de caucho.

La característica más marcada que presentó la importación de llantas de caucho de 1920 hasta 1930, fue que las cifras de importación año a año iban en aumento, lo que reflejaba un incremento constante dentro de su dinámica comercial. Si observamos detenidamente los datos presentes en el Gráfico 7, podemos ver que desde 1920 y hasta 1929 tanto las cifras expresadas en kilogramos como las expresadas en colones crecieron de un año a otro. Exceptuando el año de 1930 donde se presentó un leve descenso de la curva tanto en la cantidad de kilogramos importados como en su valor en colones respecto a años anteriores. Esta leve disminución esta ligada a la fuerte recesión económica a la que tuvieron que hacerle frente los socios comerciales costarricenses y nuestro misma economía desde 1929.

Al hablar de la importación de llantas de caucho para este período, se puede plantear que existe una marcada tendencia de crecimiento de un año respecto a otro. De igual forma, si enfrentáramos los datos de importación de automóviles del periodo 1920-1930 presentes en el Gráfico 1 con los datos presentes en el Gráfico 7, veríamos como a partir de 1920 las cifras de kilogramos importados y su valor en colones en ambos casos (más evidente en el Gráfico 7) va en un aumento casi generalizado (sin tomar en cuenta el descenso de la curva para 1921-1923 en el caso del Gráfico 1) de un año respecto al siguiente. Lo que hace pensar que la importación de llantas de caucho durante este período va en constante aumento debido a la consolidación de las importaciones de automóviles y al aumento significativo en el número de automóviles que circulaban por nuestros caminos y que hacían uso de las llantas.

A lo largo de esta sección del capítulo hemos tratado de mostrar la dinámica de importación de tres productos ligados estrechamente a los automóviles. Como hemos podido corroborar la 
importación de dos de los tres productos estuvo muy de la mano con la dinámica de importación de automóviles, al punto que siguieron los mismos parámetros de crecimiento. El otro producto, el asfalto, sin bien no compartió la dinámica de crecimiento del automóvil durante todo el período en estudio, sí presento grandes semejas en su desarrolló durante la tercera década del siglo XX, momento en el cual las importaciones de automóviles se estaban consolidando, y el automóvil podía ser considerado como un objeto propio y común dentro del paisaje costarricense.

\section{Países de procedencia de las importaciones de automóviles y afines.}

Un elemento que debe tomarse en cuenta a la hora de analizar la dinámica de importación costarricense y la aparición del automóvil dentro de dicha dinámica, son los países de dónde provenían los automóviles que llegaban al país. Como se mencionó al inicio del capítulo, nuestro país desde mediados del siglo XIX tenía vínculos comerciales con algunas de las economías más poderosas de la época, entre las que estaban Reino Unido, Alemania así como EE.UU. y algunos países latinoamericanos, como es el caso de Chile. A lo largo de nuestra historia el Reino Unido (Inglaterra) se caracterizó por ser uno de nuestros principales socios comerciales (hoy en día esto ha cambiado), muchos de los productos que se importaban desde mediados del siglo XIX y todavía durante el primer tercio del siglo XX, provenían de dicho país. Los automóviles y productos afines deben considerarse como una excepción a dicho postulado.

$\mathrm{Si}$ bien es conocida la gran trayectoria que tiene Inglaterra como país productor de inventos científico-tecnológicos y como país productor de automóviles desde fines del siglo XIX, esta tradición no tuvo una influencia tan marcada en lo que fue la dinámica de importación de automóviles y afines a nuestro país. Decimos que la tradición inglesa casi no peso porque el principal sitio de donde se importaban los automóviles y los productos afines lo fue desde un principio, EE.UU. seguido un poco distante por Inglaterra. Reflejo de ello es que para 1907, punto de inicio de esta investigación, los automóviles que entraron a nuestras fronteras provenían únicamente de EE.UU. (a partir de dicho año y hasta la fecha EE.UU. se han convertido en el principal país desde donde se importan automóviles a Costa Rica). Durante los primeros diez años del siglo XX, el número de países desde donde se importaban automóviles se fue ampliando pero aún así EE.UU. se mantuvo como la principal nación desde la cual se importaba. Esto puede deberse a varios factores, entre los que destacan: la cercanía de Estados Unidos con nuestro país, 
lo que a su vez hacia que la cantidad de dinero que se pagaba por el transporte de un automóvil vía marítima fuera menor debido a que la distancia era mucho menor respecto a Europa. Otra de las posibles razones que incidieron en que los Estados Unidos fueran el sitio predilecto, de donde se importaban los automóviles a Costa Rica, puede radicar en el peso y la influencia tan importante que tenía la industria automotriz estadounidense a nivel americano y posteriormente a nivel mundial. Recordemos que fue en Estados Unidos, donde se desarrolló lo que luego se conocería como la producción en masa de automóviles y de donde surgiría uno de lo autos más revolucionarios en la historia automovilística, tanto por su diseño como por su bajo costo, el Ford T, siendo Henry Ford y su empresa las propulsoras de estos hechos.

La ultima razón posible para el predominio estadounidense en las importaciones de automóviles a Costa Rica, es el papel que podrían haber jugado los extranjeros, principalmente estadounidenses ligados a las plantaciones bananeras, dentro de la dinámica de importación de vehículos automotores. Hacemos mención de la influencia de dichos extranjeros, ya que podrían hacer sido ellos quienes importaron los primeros automóviles a nuestro país, para su uso personal dentro de las denominadas “zonas americanas", presentes en las regiones bananeras, y al ser estadounidenses, probablemente los automóviles que importarían serian autos de fabricación estadounidense. Debemos aclarar que lo expuesto anteriormente más que ser una verdadera causa, es una hipótesis que debe ser sometida a un proceso de investigación mayor, el cual puede dar para realizar toda una nueva investigación.

Para comprender de mejor manera este proceso de importación de automóviles y productos afines sistematizaremos la información correspondiente al período 1907-1930 en cinco cuadros presentes en los anexos en donde se mostraran la cantidad anual de kilogramos importados y su valor en colones dependiendo del país de procedencia. Cada cuadro sistematizará la información correspondiente a un producto de importación. Los productos a tomar en cuenta serán: automóviles, autocamiones, gasolina, asfalto y llantas de caucho.

Una vez sistematizada la información podemos apreciar que para el rubro de automóviles importados, los socios comerciales fueron bastantes, pero destaca el papel desarrollado por Estados Unidos, Alemania, Inglaterra y en menor medida Francia. Los tres primeros se caracterizan por ser los principales socios comerciales costarricenses, tanto en lo que a importación como a exportación de bienes y productos se refiere. En relación con los autocamiones podemos decir que sus datos presentan rasgos muy similares a los presentados por los automóviles, donde 
destacan como principales países de importación además de Estados Unidos, Alemania y en menor medida Panamá, aunque el caso de Panamá es un caso que debe interpretarse como un país re exportador.

Entrando de lleno en lo que es el análisis de los productos afines a los automóviles, podemos decir que la dinámica de importación y los socios comerciales no varían mucho. Estados Unidos sigue siendo el principal país desde donde se importan los productos, en el caso de la importación de gasolina a él se suman Panamá y Perú. Respecto a la importación de asfalto, de nuevo Estados Unidos es el principal país desde donde se importa y en este caso en particular, casi el único socio comercial. Finalmente lo que es la importación de llantas de caucho presenta nuevamente a Estados Unidos como nuestro principal socio, pero esta vez hay un número mayor de socios, en este sentido destacan Alemania, Inglaterra (Reino Unido) Francia y Panamá.

En términos generales y siguiendo la información sistematizada en los Anexos 1, 2, 3, 4 y 5 podemos concluir que si bien en la dinámica económica de importación de automóviles y productos afines durante nuestro período de estudio, participaron una variedad importante de países, nuestro principal socio comercial en estas instancias lo fue Estados Unidos. Situación que hasta el día de hoy se mantiene.

\section{Conclusiones.}

La importación de automóviles y afines a Costa Rica durante el período en estudio estuvo marcada por el constante crecimiento que caracterizó dichas importaciones. Un crecimiento que a lo largo del período fue muy marcado, pero que ha veces quiso presentar rupturas, las cuales se debieron principalmente al contexto tanto político como económico que rodeo la dinámica de importación tanto mundial como costarricense. Elementos tales como la I Guerra Mundial, la crisis de 1929 y la depresión que se inició en los años treinta, fueron factores a los cuales tuvo que hacer frente el proceso de importación automovilística. Elementos que como lo reflejan las cifras si tuvieron cierta influencia sobre las importaciones, pero que al final no lograron detener su constante crecimiento. 


\section{Capítulo II}

\section{Las leyes y el automóvil.}

\section{Introducción.}

Desde la aparición de los automóviles hacia fines del siglo XIX, su utilización como un medio de transporte innovador y su posterior consolidación como mecanismo de trasporte a lo largo del siglo XX, las sociedades se han visto en la necesidad de regular y legislar el transitar de los mismos. Costa Rica no fue la excepción.

Con la llegada de los primeros automóviles a Costa Rica ha inicios del siglo XX y el aumento posterior en la importación de los mismos a través de los años; la circulación de automóviles por las ciudades se convirtió en una actividad hasta cierto punto común y constante dentro de la sociedad costarricense. Con el paulatino aumento que se iba dando de la flota vehicular y lo que esto venía a significar para toda la sociedad, los gobernantes vieron la necesidad de dictar una serie de leyes con el fin de ordenar y regular la circulación de vehículos automotores dentro las ciudades.

\section{Primer intento por regular el transitar de automóviles en el Valle Central: Reglamento para el servicio de automóviles en la ciudad de San José.}

Con la aparición de los automóviles dentro del espacio físico de las ciudades, surge la necesidad de dictar una serie de leyes y reglamentos que tienen como principal objetivo el guiar, regular y ordenar el transitar de los mismos y su tenencia. Es así como en el año 1910 se da un primero intento por parte de las autoridades pertinentes de poner en marcha un reglamento en el cual se encontraran todas aquellas reglas y leyes que debían de acatar los conductores de automóviles. Reglas que aparte de buscar sistematizar el transitar de los vehículos también establecía una serie de requisitos con los cuales los automóviles debían cumplir para circular sin ningún inconveniente por las calles costarricenses. Dicho reglamento es conocido como el Reglamento para el servicio de automóviles en la ciudad de San José. ${ }^{3}$

El principal motivo por el cual surge este reglamento, aparte de los ya expuestos, radica en que con la importación de automóviles que se venía dando desde los primeros años del siglo XX, para 1910 ya existía una cantidad importante de automóviles, los cuales circulaban libremente

3 Costa Rica [leyes], Colección de leyes y decretos, II semestre, 1910. Págs. 77 y 78. 
y sin ninguna restricción por las calles de las ciudades. Al ir el número de automóviles en constante crecimiento (como se puede observar en el capítulo I), las autoridades ven la necesidad de dictaminar un grupo de reglas que vinieran a sistematizar y a ordenar la circulación de los vehículos automotores así como también la relación que tenían los mismos con el resto de medios de transporte de la época y con los mismos peatones.

El Reglamento para el servicio de automóviles en la ciudad de San José promulgado en 1910, contaba con varias características, pero las tres más importantes y que vienen a darle un elemento de particularidad a dicho reglamento son: primero, el reglamento estaba compuesto por diez artículos.

Segundo, era un reglamento sumamente básico en el cual solo se estipulaban generalidades propias de conducir un automóvil y de los mismos vehículos. Esto a su vez producía que muchas de las acciones y actitudes desarrolladas a diario durante la conducción de un automóvil no se encontraran estipuladas dentro del reglamento y por lo tanto no fueran reguladas.

Tercero y final, el reglamento tenía un carácter local. Se plantea que el reglamento tenía un carácter local ya que como su mismo título lo dice, tenía como objetivo regular el servicio de automóviles en la ciudad de San José, dejando de lado aquellas ciudades y pueblos por los cuales pudieran circular en algún momento automóviles. Esto hace ver que el reglamento mismo fue diseñado solamente para la ciudad de San José y que su aplicación se limitaba a la ciudad capital y no presentó en ningún momento intenciones de convertirse en un reglamento que pudiera ser aplicado a nivel nacional. Como ya vimos, el Reglamento para el servicio de automóviles en la ciudad de San José presentaba una serie de características generales muy particulares.

Como mencionamos anteriormente, dicho reglamento estaba constituido por diez artículos. Cada uno de los artículos tenía un objetivo particular. En el artículo $1^{0}$ se establece un registro de automóviles en esta capital, á cargo de la Agencia 2a Principal de Policía. En dicho registro se hará constar: el nombre del dueño a quien pertenece el vehículo; si este es para servicio público o particular; los caballos de fuerza; el número de asientos de que dispone; la declaración de dos peritos que garanticen la circunstancia de encontrarse el automóvil en buen estado. Sin la previa inscripción, no puede ponerse a servicio ningún automóvil. En el artículo $2^{0}$ .se establece que los Jefes Superiores de la Policía activa, en cualquier momento, pueden ordenar la revisión de automóviles e impedir que se usen, si no estuvieren en buenas condiciones; pero al perjudicado le queda recurso para ante el Agente $2^{0}$. Principal de Policía. 
El tercer artículo plantea que los automóviles que se destinen al servicio del público deben llevar a la vista la tarifa de precios, con la aprobación del Agente $2^{0}$. La legislación establecía en el artículo $4^{0}$. que todo automóvil tiene que estar provisto de pito y campana de alarma y llevar en la parte trasera, en caracteres visibles el número de orden que le haya cabido en la inscripción. En cuanto al oficio de chofer, el artículo $5^{0}$. plantea que quien deseare dedicarse al oficio de chauffeur o motorista de automóvil debe hacerse inscribir en la misma Agencia de Policía, previa comprobación de su bien probada competencia, de su notoria buena conducta y de ser mayor de edad. Es condición indispensable no haber sido juzgado nunca por ebriedad. Las mujeres no pueden ser admitidas como motoristas. Los artículos seis y siete establece que los conductores de automóviles correrán estos por el lado derecho de la calle, según sea la carrera que lleven y que se cancelará la patente de conductor a quien se penare más de dos veces por faltas cometidas en el oficio, y de la cancelación se dará aviso al público en el periódico oficial.

En lo que respecta a la iluminación que debe poseer todo automóvil el artículo $8^{0}$. plantea que durante las horas de la noche, desde las seis de la tarde, todo automóvil deberá llevar encendidas sus luces, que serán de una potencia capaz de dar claridad sin causar molestias a la vista.

Finalmente en el artículo 9 y 10 respectivamente se establece que dentro del perímetro de la ciudad, la velocidad máxima de las carreras será de quince kilómetros por hora. Se tocará alarma al atravesar las bocacalles o al doblar las esquinas y que cualquier infracción de este Reglamento será juzgada y penada por el Agente Principal de Policía, de conformidad con las prescripciones correspondientes del Libro III, Título I del Código Penal.

Como hemos podido observar, cada uno de los artículos estipulados en el reglamento de 1910 hace referencia a un tema en específico. Pero a pesar de que cada uno de los diez artículos hace referencia a un elemento en particular, el reglamento en su totalidad presenta grandes vacíos, los cuales se quiera o no, convierten al reglamento de 1910 en un reglamento básico y muy general. Decimos que básico y muy general porque deja muchas interrogantes, así como elementos a juicio de cada conductor.

Finalmente es importante hacer mención que si bien el reglamento es bastante criticable y presenta una serie de fallos, este es el resultado o más bien la reacción de las autoridades ante el proceso de introducción del automóvil a la sociedad costarricense, y como tal es de alabar la preocupación que presentaron nuestras autoridades por regular y organizar el transitar de este 
nuevo medio de transporte por nuestras ciudades. De igual forma es importante reconocer el papel jugado por el Reglamento para el servicio de automóviles, como base para la futura ley de tránsito.

\section{La primera Ley de Tránsito de Costa Rica. 1926}

Como vimos en el primer capítulo de esta investigación, la importación de automóviles durante el período en estudio, se caracterizó por ser un proceso de constante evolución, el cual se consolidó durante la década de 1920. Es en este período de consolidación de las importaciones automovilísticas donde surge y se llega a desarrollar la que es considerada como la primera ley de Tránsito de Costa Rica. Dicha ley fue promulgada en el mes de julio de 1926, estando en el poder el presidente Ricardo Jiménez Oreamuno. La ley tiene como nombre Ley de Tráfico.

Antes de entrar de lleno en el análisis de la ley de Tráfico y el contenido de la misma, es importante hacer una pequeña mención del contexto en el cual surgió dicha ley. Como lo planteamos al inicio de este apartado, durante la década de 1920 la importación de automóviles en Costa Rica se estaba consolidando. Dicha proceso de consolidación estaba causando a su vez un fenómeno muy importante a nivel automovilístico, un crecimiento importante de la flota vehicular.

El crecimiento de la flota vehicular en nuestro país puede considerarse como la principal causa para la promulgación de la primera ley de tránsito. En otros términos, las autoridades vieron que la cantidad de automóviles estaba creciendo a un ritmo constante y que si no realizaban una serie de cambios radicales en el reglamento anterior (1910), el transitar de los automóviles, su relación con los peatones y la misma inscripción y posesión de automóviles se iban a convertir en un serio problema para la el actual gobierno y los gobiernos entrantes. Es así como el gobierno encabezado por Ricardo Jiménez ve la necesidad de promulgar la primera ley de tránsito en la historia de Costa Rica.

Entre las particularidades de la Ley de Tráfico de 1926, encontramos que la misma estaba formaba por 65 artículos, los cuales estaban agrupados en 7 diferentes capítulos. Cada uno de los 7 capítulos estaba destinado o tenia como objetivo encargarse de un elemento del tránsito o de los vehículos en particular. La composición y distribución de la ley es la siguiente: El capítulo I titulado De la inscripción de vehículos-automóviles esta compuesto de once artículos, los cuales 
giran principalmente en relación a la inscripción de los automóviles y a lo relacionado con la obtención de placas para cada vehículo. Tal vez uno de los elementos más importantes dentro de este capítulo sea la mención que se hace de la Dirección General de Tráfico ${ }^{4}$ la cual será la institución u órgano superior encargado de todo lo referente a los automóviles y su transitar. En este capítulo también se encontraran todos los datos y especificaciones técnicas que se deben suministrar para poder inscribir un automóvil.

En el capítulo II, el cual esta constituido por seis artículos y uno denominado transitorio se encuentran estipulados todos los elementos referentes a la inscripción que debe hacer toda persona que quiera contar con un permiso para ser conductor de automóvil. En este mismo capítulo se hace mención del nuevo Registro de conductores de vehículos-automóviles ${ }^{5}$ así como también del examen que deben realizar aquellas personas que aspiren a ser conductores. De igual forma se hace referencia a la libreta de conductores, la cual es considerada como la versión antigua de la actual licencia de conducir. Es importante también mencionar que la legislación de 1926, y especialmente el capítulo II no hacen mención en ningún momento de la posibilidad que puedan tener las mujeres como conductoras, esto hace pensar que todavía para este año, las mujeres en Costa Rica no contaban con la autorización de conducir un automóvil o autocamión. Este argumento esta desde la legislación dictada en el año 1910, y vemos que para la primera ley de tránsito se mantuvo sin ninguna modificación.

El Capítulo III se titula De la inscripción de rodados de tracción animal y sus conductores. Este tercer capítulo es un capítulo muy peculiar debido a que hace referencia a todos aquellos medios de transporte que sean impulsados o jalados por fuerza animal. El capítulo nos muestra que en 1926 era todavía común ver coches y carretones tirados generalmente por caballos en las ciudades. Lo peculiar de este capítulo esta en que la Ley de Tráfico establecía que tanto el vehículo tirado por fuerza animal como su conductor debían contar con un permiso expedido por la Dirección General de Tránsito para poder circular sin ningún inconveniente.

El cuarto capítulo gira en torno a los impuestos que debían pagar los dueños de automóviles trimestralmente. En el mismo se establece una tabla de cobro en la cual cada vehículo dependiendo del número de pasajeros que pudiera transportar, debía cancelar cierto monto. Los cobros eran realizados por las Tesorerías de las Municipalidades de San José, Cartago, Alajuela y Heredia.

El capítulo cinco relacionado al tráfico en general es el que cuenta con mayor número

$4 \quad$ Costa Rica [leyes], Colección de leyes y decretos, II Semestre, 1926. Pág. 28.

5 Ibíd. Págs. 30 y 31. 
de artículos, veinte y tres en total. El mismo puede ser considerado como un capítulo referente a generalidades, las cuales van desde la definición de términos como "conductor", "tráfico general”, "rodado", “calle de una sola vía”. Hasta el establecimiento de los sitios por los cuales deben transitar los peatones y los vehículos.

De la Dirección General de Tráfico se titula el capítulo VI, el cual esta constituido por cinco artículos, en estos cinco artículos se establecen los derechos, deberes y potestades con las que cuenta la Dirección General de Tráfico. El principal deber asignado a la Dirección General de Tráfico consistía en "[...] dictar todas aquellas medidas que juzgue pertinentes a fin de evitar los accidentes que puedan producirse en el tráfico general". ${ }^{6}$

El último capítulo (VII) esta constituido por ocho artículos en los cuales se establecen las responsabilidades de los dueños y conductores de automóviles tanto privados como de servicio público, en caso de accidentes en perjuicio de personas o bienes. Las infracciones a cualquiera de los artículos presentes en esta ley implicaran multas que iban desde los cinco hasta los doscientos cincuenta colones. Finalmente el capítulo presenta una lista de aquellos automóviles que son exonerados de realizar cualquier pago de impuestos. Dichos automóviles en su mayoría pertenecen a los presidentes de los supremos poderes, los secretarios de Estado, la Cruz Roja, los bomberos y las ambulancias de los cuerpos de policía.

Una vez concluido el análisis de los siete capítulos que conforman la Ley de Tráfico, podemos definir la misma como una ley muy completa. Con la promulgación de dicha ley, las autoridades encargadas buscaron no cometer los mismos errores que se habían cometido dieciséis años atrás en el Reglamento para el servicio de automóviles en la ciudad de San José. Otro elemento a rescatar en el análisis de esta primera ley de tránsito, es que la misma presentaba un carácter más nacional, aunque sin dejar de lado ese apego a las cuatro principales ciudades del Valle Central.

Es importante resaltar el estudio del contexto llevado a cabo por las autoridades, ya que sin ese estudio es muy probable que la ley no hubiera estado apegada a la realidad automovilística nacional y se hubiese dejado de lado el proceso de consolidación en materia de importación de automóviles que se venia dando durante la década de 1920, proceso que a fin de cuentas es determinante en la promulgación de la Ley de Tráfico de 1926.

6 Ibíd. Pág. 38. 


\section{Reglamento para el servicio de automóviles en la ciudad de San José versus primera Ley de Tránsito de Costa Rica.}

Con la promulgación en 1926 de la Ley de Tráfico el transitar de los automóviles por las ciudades se convirtió en una actividad sumamente regulada. Lo que vino a significar un marcado cambio en relación a la legislación anterior, la cual se caracterizaba por ser muy general y presentar una serie de fallos. La puesta en marcha de la ley de 1926 a partir del 1 de octubre del mismo año, tenía como objetivo principal sustituir el incompleto reglamento que regía el tráfico de vehículos automotores en nuestro país desde hacia dieciséis años.

Ahora bien es importante realizar un análisis en conjunto de ambas leyes, en el cual se busca realizar una comparación de las mismas a fin de identificar las principales diferencias entre una y otra. Dicha comparación permitirá a su vez, ver la evolución que se fue dando de la legislación referente a los automóviles y como el contexto jugo un papel importante para la promulgación de ambas leyes.

La primera diferencia que se puede percibir a la hora de comparar ambas legislaciones es el carácter nacional que presenta la ley de 1926, respecto al reglamento de 1910. Si bien en la Ley de Tráfico se sigue dando énfasis a las principales ciudades del Valle Central, su contenido esta desarrollado de manera tal que las leyes que ahí se contemplan perfectamente pueden ser aplicadas a cualquier otra región del país, mientras que con el reglamento de 1910 esto no se podría hacer, debido a que el mismo es un reglamento pensado y dictado para regular solamente el transitar de vehículos automotores por las calles de la ciudad de San José, por lo que se apega únicamente a la realidad automovilística josefina.

Otra de las grandes diferencias que se presentan entre ambas legislaciones, radica en la extensión de las mismas. Mientras el reglamento municipal de 1910 esta constituido por diez artículos, en los cuales se estipulan todas las leyes, la ley de tránsito de 1926 esta constituido por 65 artículos divididos en 7 capítulos diferentes. Si bien el número de capítulos no viene a determinar la importancia que pueda tener una ley, en este caso en particular si, porque como ya vimos, el que la ley de 1926 cuente con 65 artículos agrupados en 7 capítulos hace de dicha ley una ley más completa y organizada en comparación con el reglamento de 1910.

Una característica más que viene a diferenciar ambas legislaciones es la especificidad con la que cuentan los artículos que componen la ley de 1926. Especificidad en el sentido en 
el cual los artículos presentes en la Ley de Tráfico son artículos que contemplan una serie de elementos más concretos y específicos, mientras que la anterior legislación se limitaba a conocer en términos generales dichos elementos.

La figura encargada de velar por el cumplimiento de las regulaciones de tránsito varía entre una ley y otra. Este es otro de los puntos que merecen compararse ya que mientras en el reglamento de 1910 la responsabilidad de velar por el cumplimiento del reglamento estaba en manos de los agentes de policía, para 1926 la ley sufre un cambio drástico, ya que con la creación de la Dirección General de Tráfico, surge también un cuerpo especializado de agentes subordinados a dicha dirección, conocidos como "policía de tráfico" los cuales tendrán la responsabilidad de velar por el buen cumplimiento de los artículos estipulados en la Ley de Tráfico.

Lo referente a la inscripción de conductores es el elemento final que debe analizarse comparativamente entre el reglamento de 1910 y la ley de 1926. El reglamento municipal de 1910 establecía en el artículo $5^{0}$ que el único requisito para poder ser chauffeur o motorista de automóvil era ser mayor de edad, inscribirse en la agencia de policía, nunca haber sido juzgado por ebriedad y contar con habilidad y buena conducta, además de ser hombre, ya que como el mismo reglamento lo establecía, las mujeres no podían conducir un automóvil. Para 1926 dicho apartado de la ley fue variado sustancialmente, ya que aparte de mantenerse los requisitos establecidos en el reglamento de 1910 planteaba nuevos requisitos. Uno de los requisitos y elemento más importante y novedoso en este sentido, es el establecimiento de un Registro de conductores, el cual estaba a cargo exclusivamente de la Dirección General de Tráfico. Quien no se encontrara inscrito en dicho registro no podía conducir un automóvil. También aquella persona que quisiera inscribirse como conductor debía presentar una certificación en la cual se diera fe de su buena salud, así como no contar con ningún tipo de mutilación de extremidades ni impedimento físico. Finalmente otro de los requisitos novedosos que presentaba la nueva ley, era la realización y aprobación de un examen técnico y práctico acerca del manejo de un automóvil. Sin la aprobación de este examen, la persona no podría ser inscrita como conductor ni obtener su libreta de conductor, la cual acreditaba oficialmente como conductor de automóvil.

A lo largo de esta sección hemos analizado y comparado el Reglamento para el servicio de automóvil en la ciudad de San José promulgado en 1910 así como la Ley de Tráfico dictada en 1926. Gracias a dichas leyes se ha podido determinar el proceso de evolución que fueron sufriendo las mismas, y las implicaciones que esta evolución tuvo sobre el tráfico de automóviles 
en las principales ciudades de nuestro país. Hemos podido observar a través de este análisis comparativo el cambio radical que buscaban darle las autoridades a la ley de tránsito y de la necesidad que existía de ordenar y regular la circulación de vehículos, los cuales para 1926 habían aumentado considerablemente en comparación a 1910.

\section{Conclusiones.}

Con la promulgación del reglamento del 1910 y la Ley de 1926, se buscó regular y darle orden al transitar de vehículos por las calles y caminos de Costa Rica. Dicha promulgación se da debido a la necesidad que vieron los gobiernos (tanto para 1910 como para 1926 el presidente en ejercicio era Ricardo Jiménez) que legislar una actividad como lo era el transitar de automóviles, debido al proceso de paulatino crecimiento que se estaba dando año con año dentro de la flota vehicular.

\section{Capítulo III.}

\section{La publicidad y el discurso en torno al automóvil.}

\section{Introducción.}

En el momento en que el automóvil es introducido a Costa Rica, el periódico se encuentra consolidado como el principal medio de comunicación, y los anuncios comerciales son parte importante de la información que se puede encontrar en ellos. La publicidad juega un papel importante dentro de la dinámica comercial, en parte porque es mediante ella que se informa a la población de la venta de determinados productos y de las novedades que se encuentran en el mercado. Debido al papel que juegan los anuncios periodísticos dentro del consumo nacional es que consideramos importante analizar la relación que se desarrolla entre estos y los automóviles. Para realizar este análisis dividiremos nuestro período de estudio en tres etapas.

Una primera etapa se encargará de analizar la relación que se desarrollo entre la publicidad de los periódicos y los automóviles, en el momento en que estos hasta ahora estaban siendo introducidos a la sociedad costarricense. El lapso de tiempo que abarcará esta sección del capítulo inicia en 1907 y finaliza en 1910.

Una segunda sección tendrá como misión analizar la publicidad que surgió en torno al automóvil durante la década de 1910.

Y finalmente, la tercera sección de este capítulo tendrá como objetivo analizar el proceso 
de consolidación del automóvil dentro del mercado publicitario costarricense, proceso que se llevó a cabo durante la década de 1920.

Antes de entrar de lleno con el análisis es importante hacer unas cuantas aclaraciones al respecto. Primero que nada debe quedar claro que las fuentes utilizadas para la realización de este capítulo son fuentes periodísticas. Luego y ligado a lo anterior, debe de aclararse que el capítulo esta desarrollado con base en una pequeña muestra de algunos de los periódicos que se publicaban en la época. La muestra incluye la revisión de las ediciones de La Prensa Libre de los meses de Enero, Marzo y Junio de 1908; las ediciones de La Prensa Libre de Julio, Octubre y Diciembre de 1917 y las ediciones de La Nueva Prensa de Enero, Febrero y Marzo de 1925.

\section{Aparición del automóvil en la publicidad costarricense. Inicios del siglo XX.}

El lapso de tiempo que va de 1907 a 1910 es un período en el cual se introducirán dos elementos muy importantes en el desarrollo futuro de la sociedad costarricense. Un primer elemento que surge en este período es el automóvil. El otro elemento que aparece para este periodo dentro del contexto costarricense, es la publicidad en los periódicos tal y como la conocemos hoy en día, una publicidad que sentía más preocupación por el consumidor que por el artículo mismo que estaba promocionado. ${ }^{7}$ Por lo tanto podríamos considerar este período como un período de "apariciones" de elementos que producirán un cambio tanto social como cultural a lo largo de las décadas.

La relación entre publicidad y automóvil surge al igual que surge cualquier relación entre un medio en el cual promocionar un artículo, los periódicos, y el medio mismo, en este caso el automóvil. Un primer aspecto que va a caracterizar la relación entre publicidad y automóviles en la primera década del siglo XX (en la segunda década este fenómeno se va a acrecentar todavía más) va a ser el hecho que, los anuncios más que querer presentar al automóvil como una innovación lo que van a tratar es de promocionar de manera leve los bienes y productos afines. Esta tendencia por parte de la publicidad, de brindarle más importancia a los afines que al producto mismo se debe a que en Costa Rica para esta primera década, no existía una compañía o una casa comercial que se encargara de importar automóviles, sino que cada automóvil que llegada a nuestro país era traído casi de manera personal por su dueño. Además que para esta

$7 \quad$ Patricia Vega Jiménez (compiladora). Encrucijada de la comunicación social: entre la modernidad y la sociedad de la información. San José, Costa Rica. Editorial de la Universidad de Costa Rica. 2007. Pág. 3 
primera década no existe un comercio, una venta, de automóviles tal y como las conocemos hoy en día, ni como las que se desarrollaron en la década de 1920, sino que por el contrario era muy poca la información o la publicidad respecto a los automóviles y a los productos afines a los mismos. La referencia con la que contamos, ${ }^{8}$ muestra que por lo menos para los cuatro años siguientes a la aparición del automóvil en suelo costarricense, no hay una promoción fuerte de venta de productos relacionados a los automóviles, y lo más que se llega a presentar son las ofertas de servicios "profesionales" por parte de personas que dicen tener conocimientos generales y específicos de como reparar automóviles. Esta tendencia la encontramos muy clara en el periódico La Prensa Libre de los días miércoles 1 de marzo y domingo 15 de marzo de 1908 en la cual la compañía T. MANGEL \& Cia. ${ }^{9}$ ofrece los servicios de ingeniería electrónicomecánica en caso que el sistema eléctrico del automóvil sufra algún desperfecto o simplemente quiera darle una revisión.

Es poco lo que se puede decir en esta sección respecto a la primera etapa de la relación entre la publicidad periodística y los automóviles, ya que la misma estuvo a lo largo del período, marcada por una escasa presencia, por no decir que nula, de publicidad que hiciera referencia a los automóviles o a sus afines. Y la publicidad existente, estaba más concentrada en ofrecer los servicios “profesionales” de ciertas personas. Incluso algo que puede mencionarse, es que el formato en el cual se presenta este tipo de publicidad mantiene las características y parámetros de un anuncio publicitario de finales del siglo XIX, en donde se le daba muchísimo énfasis al texto y casi no se tomaba en cuenta posibles imágenes.

En síntesis podemos decir que esta primera etapa de la relación publicidad-automóvil presenta características que hacen prever que la dinámica entre estos elementos para estos años, hasta ese momento se estaba iniciando.

\section{La publicidad en la década de 1910.}

Esta segunda etapa en la relación publicidad-automóviles esta marcada por un cambio bastante radical en cuanto a la relación misma. Planteamos que es un cambio radical ya que viene a dejar atrás cualquier elemento o cualquier tendencia que se desarrollará en la etapa anterior. En esta segunda etapa hay un cambio bastante marcado en la relación publicidad-automóvil debido a que se introducen nuevos elementos, los cuales le dan un dinamismo mayor a los anuncios.

$8 \quad$ La Prensa Libre. enero, marzo y junio. 1908.

$9 \quad$ La Prensa Libre. 1 y 15 de marzo 1908. Pág. 4 
Para esta etapa se presenta un cambio en la publicidad, cambio no solo temático, sino también un cambio en la forma en como era estructurada la publicidad. En esta etapa la publicidad atraviesa por un proceso de "modernización” ${ }^{10}$ en donde se le comienza a dar más énfasis a las imágenes, a los anuncios creativos y no ha aquellos que solo presentaban texto. De igual forma las personas encargadas de diseñar los anuncios (muchas veces eran hasta los mismos jefes de redacción o editores) centraran sus esfuerzos en captar la atención de los lectores en vez de estar resaltando elementos particulares de los automóviles.

Como lo mencionamos de manera rápida en la sección anterior, esta segunda etapa esta caracterizada por darle un fuerte énfasis y una fuerte promoción a los afines ligados a los automóviles. Esto como ya lo habíamos mencionado, se debió a que no existía en nuestro país un negocio de venta de automóviles tan fuerte como el que se desarrollaría en la década de 1920 y que sería la característica principal de esa tercera etapa de desarrollo entre publicidad y automóviles. En esta etapa la relación entre productos afines a los vehículos y los anuncios es muy fuerte y gira casi entorno a unos cuantos productos.

Los productos debido a los cuales la relación publicidad-automóvil se vuelve más dinámica son en su mayoría productos ligados al mercado de llantas y neumáticos, algo interesante si se toma en cuenta que este producto aparecerá registrado en los anuarios estadísticos de Costa Rica solo a partir de la década de 1920. Este mercado a su vez esta casi dominado por una marca en especial, la Firestone. Revisando las fuentes de las que disponemos para este período, ${ }^{11}$ observamos que más del 50\% de los anuncios encontrados en La Prensa Libre del año 1917, giran en torno a llantas o neumáticos de la marca Firestone, y en menor medida de la marca Fisk. ${ }^{12}$ Representativo de esto son las Fotos 1,2 y 3.

Esta marcada tendencia de parte de la publicidad, de promover la adquisición llantas y neumáticos sean de la marca que sean, se puede deber a que para esta segunda década del siglo $\mathrm{XX}$, las importaciones de automóviles estaban atravesando un proceso de desarrollo bastante fuerte en donde el número de automóviles que podían estar circulando por nuestros caminos año a año iba en aumento. Entrando un poco más de lleno en lo que son los anuncios en si, se puede observar a simple vista el cambio radical entre la primera etapa y esta segunda etapa. La

10 Patricia Vega Jiménez. “Encrucijada de la comunicación social....”. Pág.3

11 La Prensa Libre, julio, octubre y diciembre. 1917

12 La Prensa Libre. Sábado 7 de julio de 1917. Pág. 4. 
publicidad de esta segunda etapa (Foto 1,2,3) es muchísimo más gráfica que la de la primera etapa, debido a la utilización de imágenes como estrategia por captar la atención del público. En el caso de la publicidad correspondiente a productos afines con los automóviles, se puede ver a simple vista este proceso de cambio. Los anuncios de llantas y neumáticos marca Firestone son un reflejo de ello, ya que todas las pautas publicitarias relacionadas a dicha empresa presentan una imagen como mínimo, en donde se muestra una llanta, un neumático o algún producto relacionado a estos dos. Tanto en la Foto 1 y 2 se busca resaltar la imagen de la llanta y del neumático, utilizando imágenes de los mismos que abarque una parte importante del anuncio, de igual forma los anuncios resaltan la marca, en este caso Firestone, ya sea utilizando una tipografía llamativa como es el caso de la Foto 2 o haciendo que la palabra resalte, utilizando un fondo oscuro mientras que la tipografía o letras son de color claro, esto hace que visualmente lo primero que el lector perciba es la palabra Firestone seguido de las imágenes de neumáticos.

En el caso de la Foto 3, esta hace referencia a las llantas y neumáticos de la marca Fisk, en el anuncio se puede observar como al igual que en el caso de las llantas Firestone, el primer elemento visual que se percibe es la llanta, la cual cubre aproximadamente una tercera parte del anuncio, de igual forma se utiliza una tipografía bastante grande para hacer mención de la marca en específico y seguidamente y como dato interesante vemos una ilustración en donde se presenta un automóvil transitando por un camino, lo que es importante resaltar es la imagen misma, en donde se observa que el automóvil recorre un camino en donde se observa una casa a un lado del camino rodeada de vegetación en donde sobresalen dos palmeras. En este sentido, esta ilustración podría ser interpretada como una imagen en la cual la empresa estadounidense hace referencia al contexto "tropical" de nuestro país. Finalmente el anuncio hace referencia al origen y fabricación extranjero del neumático, planteando que son producidos en Chicopea Falls, Massachussets, EE.UU.

La Foto 3 hace referencia a una parte importante de la estrategia comercial que se empieza a utilizar para promocionar los bienes afines a los automóviles, la cual consiste en hacer referencia al origen de los mismos. Se menciona que los productos son fabricados bajo estándares de calidad muy altos en sus países de origen (países desarrollados) y que son diseñados especialmente para el contexto costarricense.

En términos generales vemos como la principal característica que presentó la publicidad en torno a los automóviles giro sobre la promoción de productos afines y estrechamente ligados a estos vehículos. 


\section{El automóvil se consolida en el mercado publicitario durante la década de 1920.}

Al igual que en el caso de las importaciones, la década de 1920 vino a significar una década de consolidación del automóvil como parte importante del mercado publicitario. Se habla de consolidación del automóvil como parte del mercado publicitario debido a que será hasta esta década en la cual la publicidad y los automóviles desarrollen un verdadero vinculo entre ellos.

Pensamos que este proceso de consolidación del automóvil dentro del mercado publicitario se desarrolló hasta los últimos diez años de nuestro nuestra investigación, debido a una especie de paralelismo que existió entre lo que fue la consolidación de las importaciones de automóviles y la consolidación de los mismos en el mercado publicitario. En pocas palabras decimos que la figura del automóvil se consolida dentro de la publicidad periodística hasta que se consolida como un producto importante dentro de las importaciones costarricenses. De ahí que ambos hechos ocurran en el transcurso de la década de 1920.

El mayor reflejo de este proceso de consolidación lo podemos ver en el cambio que se da de la segunda etapa a esta tercera etapa, en donde los productos afines pasan de ser el centro de atención (primera y segunda etapa) a ser un elemento más dentro de esta dinámica, y el los automóviles como tales, se convierten en el centro de atención.

Las fotos 4, 5 y 6 nos muestra que el centro de la publicidad cambio para esta década, y dejo de ser los productos relacionados con los automóviles a los automóviles mismos. La publicidad cambia y en términos generales los automóviles se convierten en la estrella de la publicidad tanto es así que solo para los meses de enero, febrero y marzo de 1925, aparecen seis anuncios diferentes promocionando la venta de seis marcas de automóviles diferentes en el periódico La Nueva Prensa.

Las tres fotos anteriores muestran un elemento muy importante que se dio en esta tercera etapa, la competencia entre las diferentes marcas de automóviles a través de la publicidad. En los tres anuncios se puede observar imágenes de los automóviles a los cuales hace referencia el anuncio, de igual forma se puede percibir como la idea de la publicidad además de promocionar el automóvil intenta crear una relación entre la marca (también respecto a la tipografía de cada marca) y una imagen determinada de automóvil. Vemos como las imágenes de presentan las marcas Chevrolet y Continental (MOON) tratan de presentar a sus automóviles respectivos como vehículos grandes y con características de gran lujo, mientras que la marca Ford busca presentar 
su modelo como el modelo a simple vista menos lujoso y grande, pero con grandes componentes como lo seria su arrancador electrónico. También la publicidad para el automóvil Ford busca presentarse ante el público como un automóvil con el mejor precio del mercado.

Finalmente y algo importante de mencionar es el titular que se le da a Ford en el anuncio; se presenta como el “automóvil universal” esto haciendo referencia a la gran cantidad de automóviles marca Ford que circulaban por el mundo. En el Cuadro 3 podemos encontrar las seis diferentes marcas de automóviles que se promocionaban.

De igual forma para este período aparecen nuevos elementos que vienen a mostrar que estamos ante un proceso de consolidación tanto de la importación de automóviles como ante la consolidación de estos vehículos en el mercado publicitario. Uno de estos elementos es la aparición de lo que podríamos considerar las agencias automotrices o por lo menos de las primeras tiendas o negocios encargados de vender automóviles en nuestro país. Con esto nos referimos al almacén Bolaños y Ulloa, el cual para marzo de 1925 “ofrece variedad de automóviles”. ${ }^{13}$

Es importante mencionar que el hecho que se haya dado un cambio en el sujeto de los anuncios, no determina que se haya dejado de comercializar productos relacionados directamente con los automóviles, sino que más bien este tipo de anuncios paso a segundo plano, pero siempre desarrollando sus funciones como anuncios promotores de la venta de productos para automóvil.

Finalmente, si quisiéramos resumir en pocas palabras lo mencionado a lo largo de esta sección podríamos decir entonces que para el período que va de 1920 a 1930, el automóvil se convierte en el primer actor del mercado publicitario y que los productos ligados a estos pasan a ser secundarios, pero a la vez muy importantes dentro de los anuncios periodísticos.

13 La Nueva Prensa. Sábado 14 de marzo de 1925. Pág. 3. 


\section{Conclusiones.}

Como hemos podido ver a lo largo del capítulo, la relación entre publicidad y automóviles estuvo marcada por los mismos parámetros que marcaron la evolución de la importación de vehículos automotores. Un primer proceso en el cual se daba la aparición de lo automóviles. Una segunda etapa que esta caracterizada por ser la etapa donde se da el desarrollo de una dinámica de importación y se da el proceso de desarrollo de un mercado publicitario destinado a promocionar principalmente los productos afines a los automóviles.

Y el último proceso el cual es el más complejo, y es donde se da la consolidación de las importaciones de automóviles en nuestro país y donde estos pasan a ocupar el papel principal dentro de la publicidad. En este periodo se da la consolidación del automóvil dentro del mercado publicitario costarricense.

\section{Conclusión}

La aparición del automóvil durante la primera década del siglo XX en Costa Rica, fue un hecho que tuvo gran relevancia dentro de la sociedad, a nivel económico, social y cultural. La relevancia de los automóviles dentro de la sociedad puede ser apreciada desde tres ángulos diferentes: desde las importaciones, desde la legislación y desde la publicidad periodística. En los tres casos es posible determinar la importancia y relevancia que fue adquiriendo el automóvil a lo largo del primer tercio del siglo XX.

En lo que respecta a las importaciones podemos ver que este proceso económico atravesó a lo largo de nuestro período de estudio por tres etapas importantes, una primera etapa, en la cual se da el proceso de aparición del automóvil y afines, puede ser ubicada temporalmente en la primera década del siglo XX; la segunda etapa esta marcada por un desarrollo importante de la dinámica de importación de vehículos y afines, este desarrollo es propio de la segunda década del siglo XX, y finalmente la tercera etapa la cual corresponde a la tercera década del siglo XX, se caracteriza por ser la etapa de consolidación de las importaciones de estos productos.

En el plano legal, podemos concluir que con la aparición del automóvil en la sociedad costarricense, las autoridades se vieron en la necesidad de regular el transitar de dichos vehículos por las calles de las ciudades, esto con el objetivo de brindarle una mayor seguridad tanto a peatones como conductores. Debido a esta necesidad de parte de las autoridades es que surgen 
las primeras leyes relacionadas a los automóviles. El reglamento municipal de 1910 se convierte en un primer intento por poner en práctica regulaciones al transitó de vehículos, este primer intentó si bien es de alabar, presenta una cantidad considerable de errores y omisiones. Esta serie de errores y omisiones sumado al aumentó paulatino de la flota vehicular en Costa Rica, obligan a las autoridades nuevamente, a dictar una ley mucho más completa y clara. Es así como surge la primera ley de tránsito en la historia de Costa Rica, dicha ley será promulgada en el año de 1926. En ambos casos las autoridades lo que buscaron fue que la aparición del automóvil dentro del contexto costarricense se diera de la manera más ordenada y correcta posible.

Finalmente, en lo que respecta a la publicidad que apareció en los periódicos de la época, se puede concluir que al igual que en el caso de las importaciones, los anuncios relacionados a los automóviles y a sus productos afines atravesaron tres etapas, las cuales vienen a ser a su vez, el reflejo de la evolución que fueron sufriendo estos anuncios, evolución y cambio paulatino que se dio principalmente en el objeto central del anuncio y en los elementos mismos de los cuales hace uso el anuncio para promocionar un producto determinado.

En términos generales, hemos observado que con la llegada del este medio de transporte en los primeros años del siglo $\mathrm{XX}$, se inicio todo un proceso económico, social y cultural en Costa Rica que vendría a culminar en la consolidación del automóvil como el principal medio de transporte de los costarricenses en la actualidad. 


\section{Cuadros, Gráficos e Ilustraciones.}

Cuadro 1. Importación anual de automóviles y accesorios en Costa Rica de 1907 a 1930 presentada en kilogramos y en colones.

\begin{tabular}{ccc}
\hline Año & Kilogramos Totales & Valor en Colones \\
\hline 1907 & 811 & 1621 \\
1908 & 2257.4 & 4519.53 \\
1909 & 12316.80 & 32254.44 \\
1910 & 10087 & 23847.68 \\
1911 & 20468 & 41460.20 \\
1912 & 56975.80 & 105346.47 \\
1913 & 69833.5 & 149690.68 \\
1914 & 37987.2 & 64215.79 \\
1915 & 39473.50 & 50069.20 \\
1916 & 79378.50 & 125199.78 \\
1917 & 59997 & 85305.50 \\
1918 & 7895 & 22394 \\
1919 & 50472 & 117086 \\
1920 & 175574 & 399604 \\
1921 & 70137 & 159373 \\
1922 & 59119 & 103920 \\
1923 & 100762 & 163103 \\
1924 & 244855 & 665580 \\
1925 & 301578 & 825896 \\
1926 & 471457 & 1473516 \\
1927 & 673477 & 1906224 \\
1928 & 797277 & 1984176 \\
1929 & 660695 & 1720576 \\
1930 & 112158 & 309396 \\
\hline Totales & $\mathbf{4 1 1 5 0 4 1 . 7}$ & $\mathbf{1 0 5 3 4 3 7 4 . 2 7}$ \\
\hline
\end{tabular}

Fuente: Biblioteca Virtual en Población. Centro Centroamericano de Población y Biblioteca Nacional de Costa Rica. Anuario Estadístico de Costa Rica. 1907 a 1930. 
Gráfico 1. Evolución de las importaciones de automóviles y accesorios en Costa Rica para el período. 1907-1930.

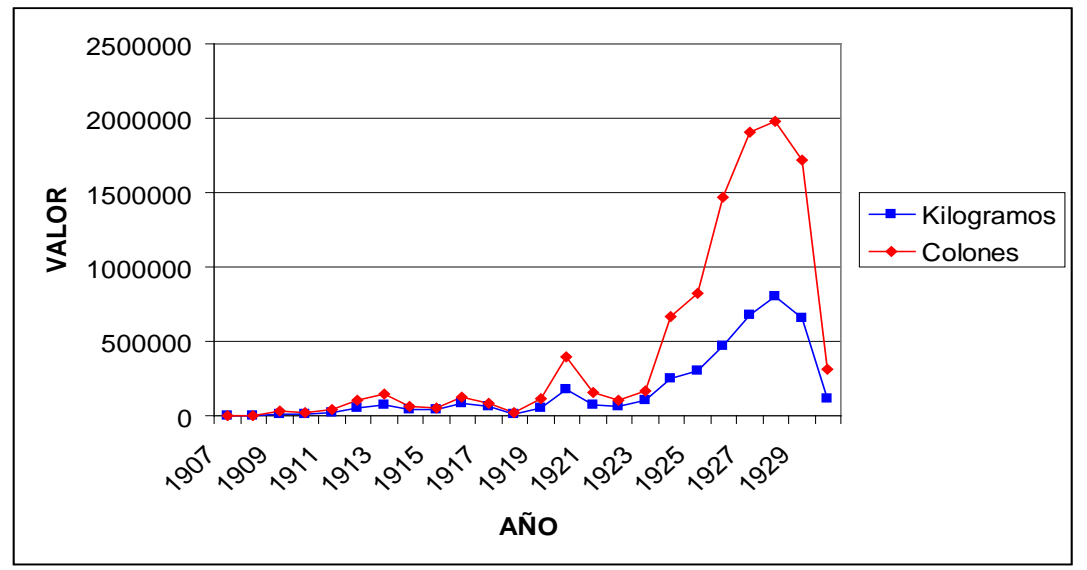

Fuente: Igual al Cuadro 1.

Cuadro 2. Importaciones anuales de autocamiones para el período de 1920 a 1930.

\begin{tabular}{ccc}
\hline Año & Kilogramos & Valor en Colones \\
\hline 1920 & 12723 & 20593 \\
1921 & 42065 & 79733 \\
1922 & 14771 & 44114 \\
9123 & 26749 & 48650 \\
1924 & 36450 & 103612 \\
1925 & 143165 & 360080 \\
1926 & 239931 & 569332 \\
1927 & 353364 & 682312 \\
1928 & 496304 & 1128748 \\
1929 & 519190 & 1131184 \\
1930 & 127071 & 226860 \\
\hline Total & $\mathbf{2 0 1 1 7 8 3}$ & $\mathbf{4 3 9 5 2 1 8}$ \\
\hline
\end{tabular}

Fuente: Biblioteca Virtual en Población. Centro Centroamericano de Población y Biblioteca Nacional de Costa Rica. Anuario Estadístico de Costa Rica 1920 a 1930. 
Gráfico 2. Tendencia que siguió la importación de camiones de 1920 a 1930 . Expresada en kilogramos importados y valor en colones.

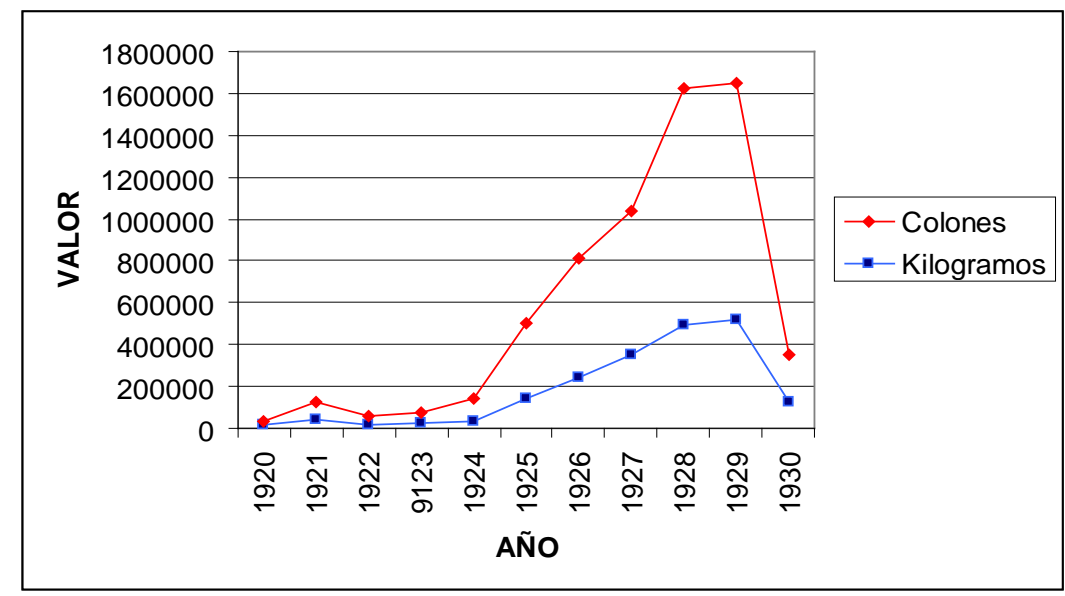

Fuente: Igual al Cuadro 2.

Gráfico 3. Importación de Automóviles y Autocamiones expresado en kilogramos. 19071930.

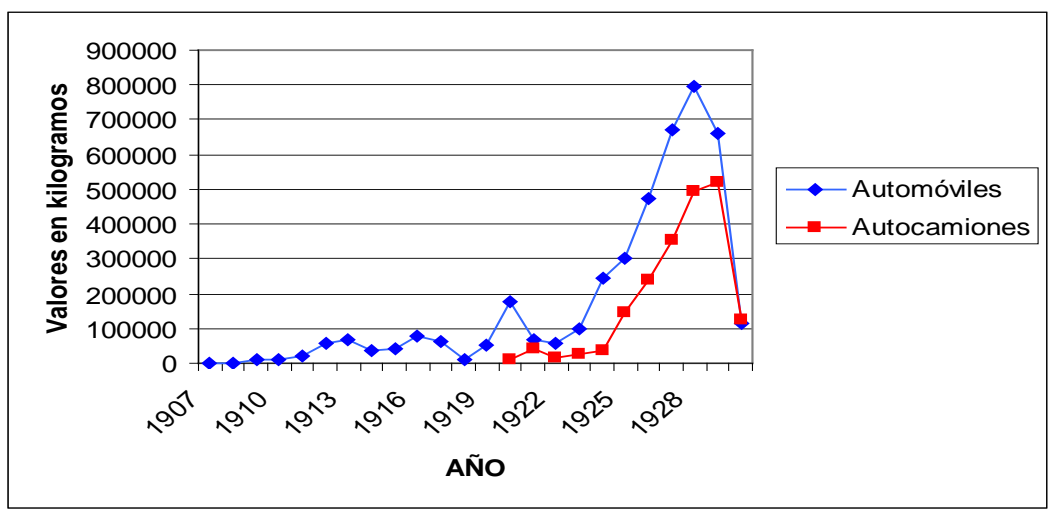

Fuente: Biblioteca Virtual en Población. Centro Centroamericano de Población y Biblioteca Nacional de Costa Rica. Anuario Estadístico de Costa Rica. 1907 a 1930.

Nota: No existe información para la importación de camiones anterior a 1920. 
Gráfico 4. Importación de Automóviles y Autocamiones expresado en Colones. 1930.

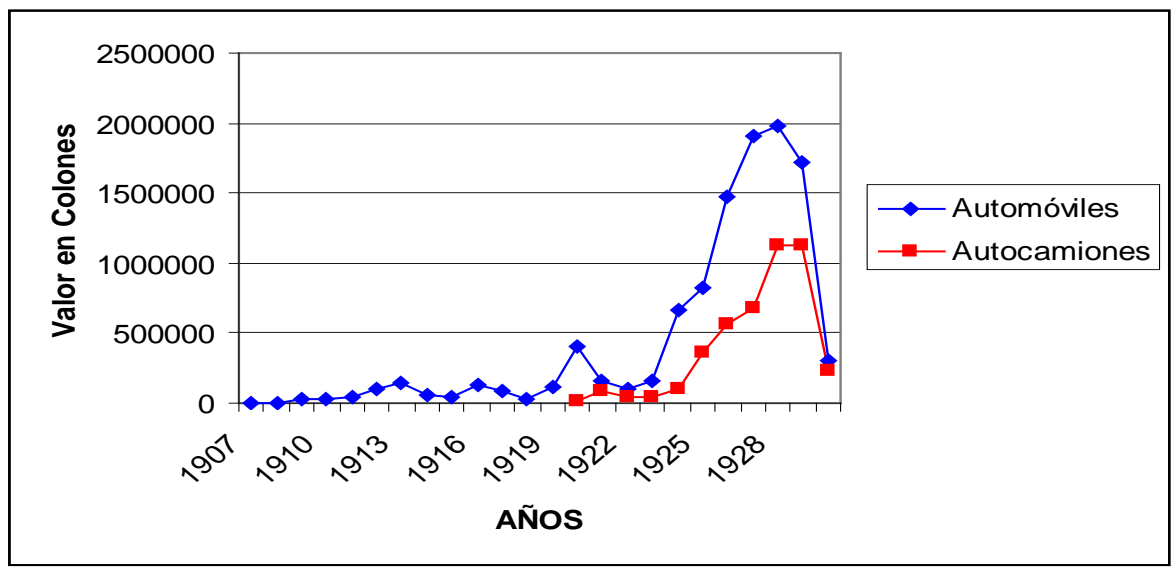

Fuente: Igual al Gráfico 3

Gráfico 5. Importación de Gasolina en kilogramos y colones. 1907-1930

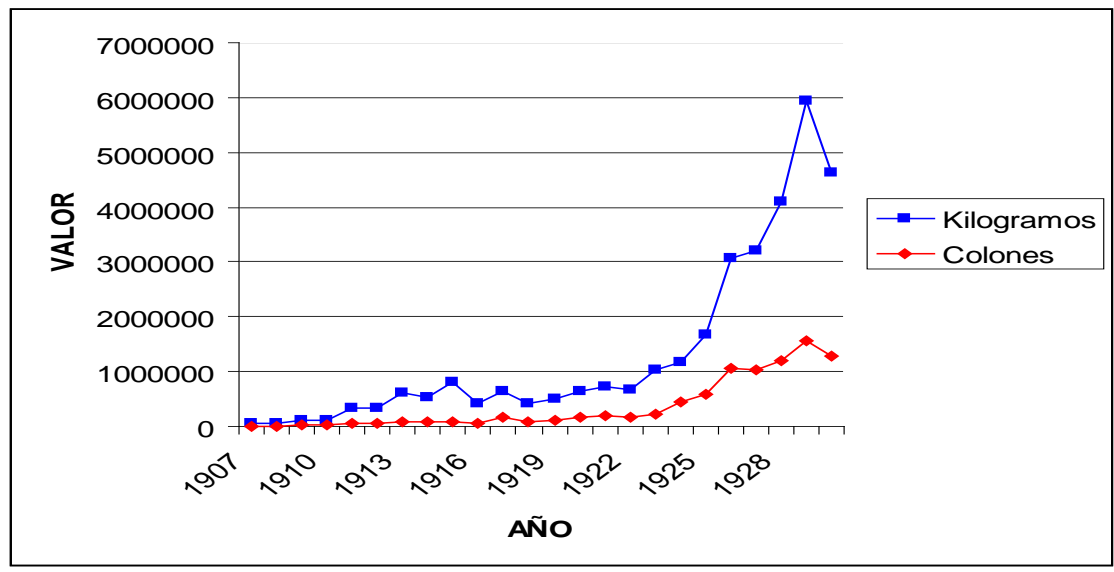

Fuente: Biblioteca Virtual en Población. Centro Centroamericano de Población y Biblioteca Nacional de Costa Rica. Anuario Estadístico de Costa Rica. 1907 a 1930. 


\section{Gráfico 6. Importación de asfalto entre 1907 y 1930 (representada en kilogramos)}

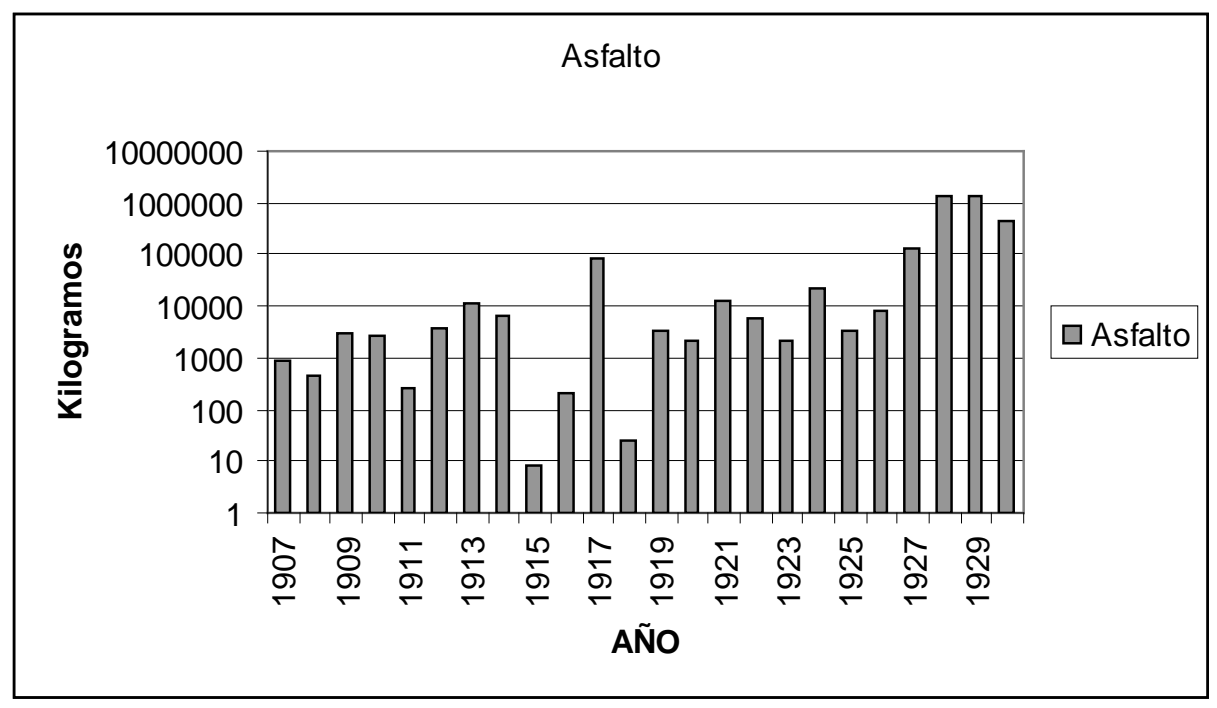

Fuente: Igual al Gráfico 5.

Nota: El año de 1917 no se considera parte de esta etapa.

Gráfico 7. Importación de llantas de caucho expresadas en kilogramos y en colones. 19201930.

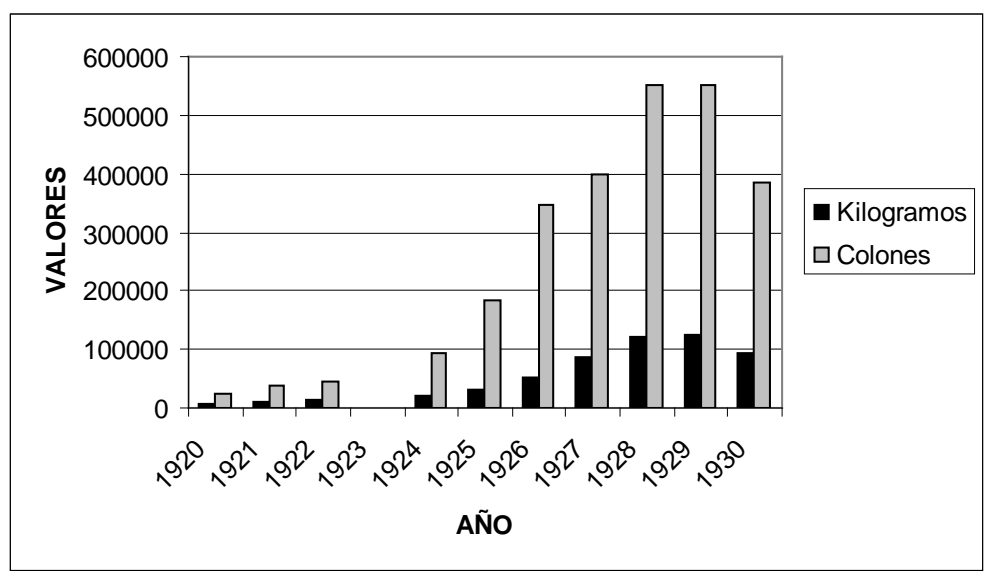

Fuente: Biblioteca Virtual en Población. Centro Centroamericano de Población y Biblioteca Nacional de Costa Rica. Anuario Estadístico de Costa Rica. 1907 a 1930.

Nota: No se encontraron dentro de las fuentes cifras correspondientes al año de 1923. 


\section{9) $9^{\circ}$ CONGRESO \\ - $\$$ CENTROAMERICANO \\ QLL IIISIORIA}

Indexaciones: Repositorio de Revistas UCR, DIALNET, Latindex, REDALYC Directorio y recolector de recursos digitales del Ministerio de Cultura de España, Directory of Open Access Journals.

Diálogos Revista Electrónica de Historia ISSN 1409-469X. Número especial 2008. Dirección web: http://historia.fcs.ucr.ac.cr/dialogos.htm

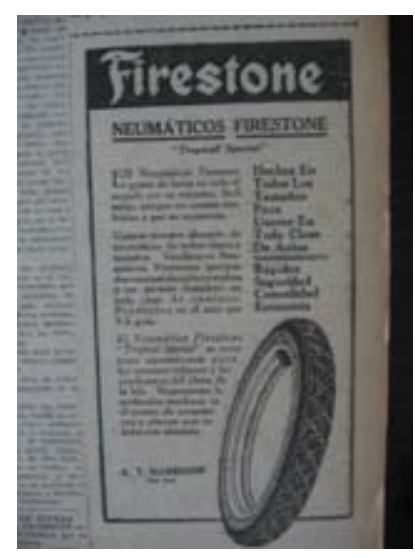

Foto 1. La Prensa Libre. 10-07-1917. Pág. 3

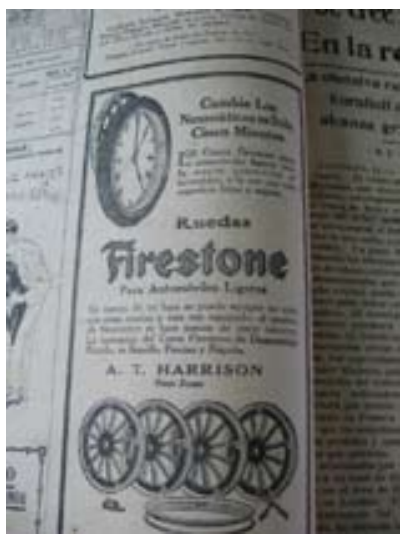

Foto 2. La Prensa Libre. 11-07-1917. Pág. 3

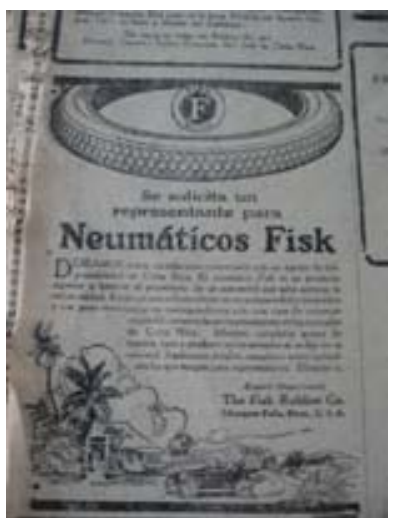

Foto 3. La Prensa Libre. 07-07-1917. Pág. 4. 


\section{9 $99^{\circ}$ CONGRESO \\ 9 $\mathrm{S}$ CENTROAMERICANO \\ of}

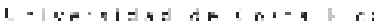

Indexaciones: Repositorio de Revistas UCR, DIALNET, Latindex, REDALYC Directorio y recolector de recursos digitales del Ministerio de Cultura de España, Directory of Open Access Journals.

Diálogos Revista Electrónica de Historia ISSN 1409-469X. Número especial 2008. Dirección web: http://historia.fcs.ucr.ac.cr/dialogos.htm

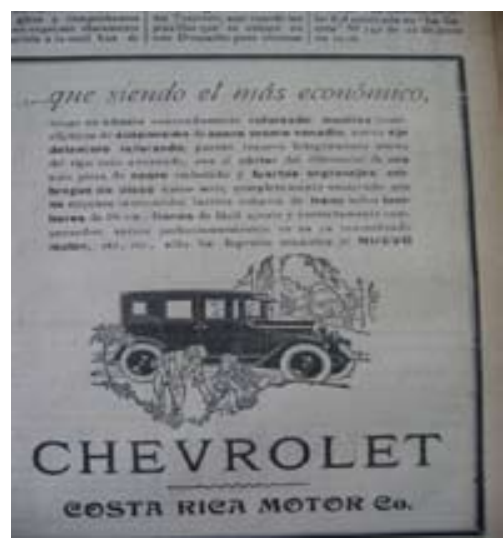

Foto 4. La Nueva Prensa. 7-03-1925.

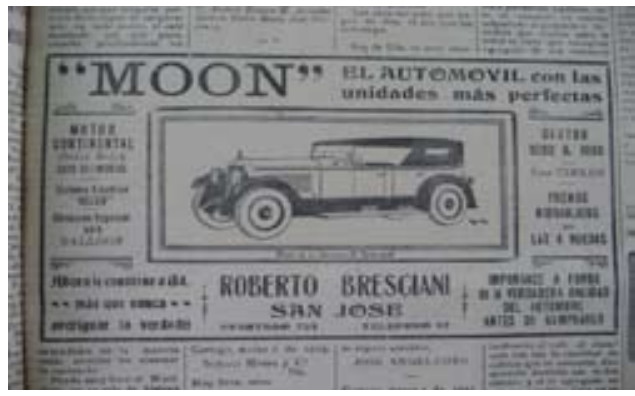

Foto 5. La Nueva Prensa. 14-03-1925

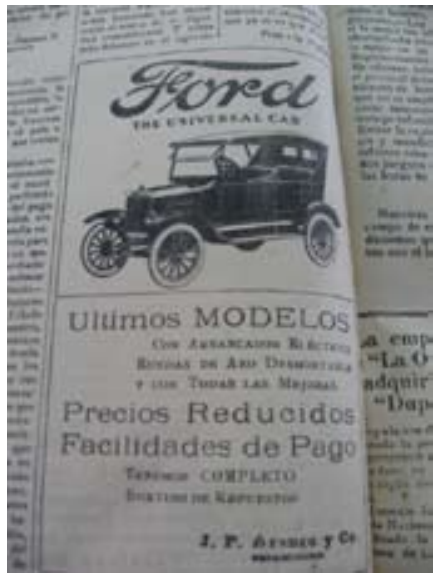

Foto 6. La Nueva Prensa. 26-03-1925.

Cuadro 3. Algunos anuncios de marcas de automóviles que aparecen en el periódico La 
9 $9^{\circ}$ CONGRESO CENTROAMIERKCANO

UL IIISIORIA

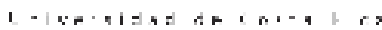

Indexaciones: Repositorio de Revistas UCR, DIALNET, Latindex, REDALYC Directorio y recolector de recursos digitales del Ministerio de Cultura de España, Directory of Open Access Journals. Diálogos Revista Electrónica de Historia ISSN 1409-469X. Número especial 2008. Dirección web: http://historia.fcs.ucr.ac.cr/dialogos.htm

Nueva Prensa para el año 1925

\section{Marca Automóvil}

Continental

Dogde

Buick

Chevrolet

Oldsmobile

Ford

\section{Fecha publicación}

24 de enero en la página 5

24 enero en la página 6

6 de febrero en la página 3

21 de febrero en la página 4

10 de marzo en la pagina 4

26 de marzo en la página 4

Fuente: La Nueva Prensa. Enero, Febrero, Marzo de 1925.

Anexo 5. Distribucion de las importaciones de llantas de caucho según país para el período 1920-1930.

\begin{tabular}{|c|c|c|c|c|c|c|c|c|c|c|c|}
\hline Año & \multicolumn{2}{|c|}{ EE.UU } & \multicolumn{2}{|c|}{ Alemania } & \multicolumn{2}{|c|}{ Francia } & \multicolumn{2}{|c|}{ Reino Unido } & \multicolumn{2}{|c|}{ Italia } & \\
\hline & $\mathrm{Kg}$ & Colones & $\mathrm{Kg}$ & Colones & $\mathrm{Kg}$ & Colones & $\mathrm{Kg}$ & Colones & $\mathrm{Kg}$ & Colones & \\
\hline 1920 & 5310 & 16809 & & & & & 3 & 10 & & & \\
\hline 1921 & 5074 & 17918 & 301 & 1729 & 3 & 2 & 8 & 52 & 50 & 264 & \\
\hline 1922 & 13129 & 43316 & 896 & 1820 & & & 33 & 219 & & & \\
\hline \multicolumn{12}{|l|}{1923} \\
\hline 1924 & 16267 & 72416 & 1648 & 8456 & 210 & 1304 & 1636 & 11176 & & & \\
\hline 1925 & 22891 & 132532 & 3033 & 17416 & 291 & 1940 & 2941 & 17724 & & & \\
\hline 1926 & 46387 & 301492 & 810 & 4760 & 226 & 672 & 3818 & 321888 & & & \\
\hline 1927 & 77305 & 343144 & 782 & 3156 & & & 6770 & 36152 & & & \\
\hline 1928 & 114461 & 521608 & 394 & 1596 & 1825 & 8260 & 3798 & 20160 & & & \\
\hline 1929 & 119966 & 529200 & 371 & 652 & 1412 & 188 & 3756 & 17496 & 76 & 212 & \\
\hline 1930 & 93526 & 379028 & 94 & 276 & 82 & 252 & 1182 & 5388 & 75 & 260 & \\
\hline TOTAL & 514316 & 2357463 & 8329 & 39861 & 4049 & 12618 & 23945 & 430265 & 201 & 736 & \\
\hline \multicolumn{2}{|c|}{ España } & \multicolumn{2}{|c|}{ Panamá } & \multicolumn{2}{|c|}{ Cuba } & \multicolumn{2}{|c|}{ Holanda } & \multicolumn{2}{|c|}{ Bélgica } & \multicolumn{2}{|c|}{ Otros } \\
\hline \multirow[t]{4}{*}{$\mathrm{Kg}$} & Colones & $\mathrm{Kg}$ & Colones & $\mathrm{Kg}$ & Colones & $\mathrm{Kg}$ & Colones & $\mathrm{Kg}$ & Colone & $\mathrm{Kg}$ & Colones \\
\hline & & 1133 & 6766 & & & & & & & 25 & 54 \\
\hline & & 4209 & 19273 & & & & & & & & \\
\hline & & 225 & 768 & & & & & & & & \\
\hline \multirow[t]{7}{*}{40} & 204 & 255 & 928 & & & 5 & 24 & & & 2 & 16 \\
\hline & & 1728 & 14024 & & & 4 & 16 & & & & \\
\hline & & 1031 & 9096 & & & & & & & 12 & 40 \\
\hline & & 1735 & 6576 & 58 & 420 & 45 & 284 & & & 82 & 140 \\
\hline & & 86 & 788 & & & & & & & & \\
\hline & & 383 & 504 & & & & & 180 & 1748 & 92 & 400 \\
\hline & & 40 & 385456 & & & & & & & & \\
\hline 40 & 204 & 10825 & 444179 & 58 & 420 & 54 & 324 & 180 & 1748 & 213 & 650 \\
\hline
\end{tabular}

Fuente: Biblioteca Virtual en Población. Centro Centroamericano de Población y Biblioteca Nacional de Costa Rica. Anuario Estadístico de Costa Rica. 1920 a 1930.

Nota: No se encontraron dentro de las fuentes cifras correspondientes al año de 1923. 